\title{
Research of characteristics of PJSC "Koks" coal and coke dust fuel briquettes
}

\author{
Vyacheslav Solodov ${ }^{1,2}$, Tatyana Cherkasova ${ }^{1}$, Nikolay Kolmakov ${ }^{2}$, Sergey Subbotin ${ }^{1,2}$, and \\ Yuriy Radchenko ${ }^{3}$ \\ ${ }^{1}$ T.F. Gorbachev Kuzbass State Technical University 28, Vesennyaya, Kemerovo, Russia, 650000 \\ ${ }^{2}$ PJSC «Koks» 6, $1^{\text {st }}$ Stakhanovkaya, Kemerovo, Russia, 650021 \\ ${ }^{3}$ Belarusian State Technological University, Minsk, Belarus
}

\begin{abstract}
Known methods for the production of fuel briquettes are studied and an analysis of their qualitative characteristics is carried out in the present work. Based on the analysis of existing methods, pilot briquetting of a mixture of PJSC "Koks" coal and coke dust with various types of binder was carried out. Within the framework of studies, the main requirement for raw materials was the absence of demand for it in the market and in the technological processes of existing industries. It has been established that substandard urea is the best binder of the considered ones, since briquettes with its use have high strength and low sulfur content. Comparative briquetting by single and impulse pressing methods was carried out. It is shown that greater briquette strength is achieved by impulse pressing method. It has been established that the process of utilizing finely dispersed carbon-containing wastes is aimed not only at obtaining a new marketable type of fuel and at saving natural resources, but also at improving the environmental situation through the rational use of secondary material resources.
\end{abstract}

\section{Introduction}

Every year there is an increase in energy prices. The requirements for the quality of the final product are constantly increasing, therefore, a deeper cleaning and preparation of raw materials and intermediates is required, which in turn leads to the generation of additional waste. At the same time, there is a constant effort to reduce the environmental load in the world, where dumps and tailings are unacceptable. One of the rational solutions to these problems is the recycling of carbon-containing wastes of coal mining and coal processing enterprises to produce a marketable product in the form of fuel briquettes.

Briquetting is a process of mechanical conversion of coal or coke dust into lump fuel briquettes having certain characteristics: shape, size and weight. Many methods for briquetting coke and coal dust, fines, sludges and other types of finely dispersed carboncontaining waste products are known. Having studied these methods, we can conclude that technologies for producing briquettes with the addition of a binder are the most efficient. As a result of adding a binder, the strength characteristics of the briquette are improved, but 
it is worth remembering that it is necessary to study in detail the properties of the binder in order to know the effects of the products of combustion of the binder on technology, hardware and ecology.

Previously, many researchers have repeatedly conducted tests to obtain fuel briquettes from various carbon-containing materials without the use of a binding agent. A positive briquette strength test result was achieved only in the case of additional heat treatment before or during the briquetting process. The briquettes produced without heat treatment had low strength indicators, which is unacceptable during loading and transportation of briquettes. In most cases, the sintering coal additive was used and heat treatment was carried out to a temperature of $250^{\circ}-400^{\circ} \mathrm{C}$, in order to produce fuel briquettes which included sintered coal char. This method allows to produce fuel briquettes with acceptable strength, reduced yield of volatile substances and increased calorific value in comparison with briquettes made of coal or wood. But there are a number of drawbacks in the application of this method such as the need to capture the gas released in the heat treatment process, the high cost of equipment for the production, as well as the significant cost of energy to maintain the temperature during the heat treatment [1]. Briquetting methods with the use of binding agents are the most attractive, in view of the simplicity of the flowsheet and the equipment used. A rational approach to the production of fuel briquettes is the use of carbon-containing waste of coal mining and coal processing, as well as the chemical industry waste.

The most common types of binders are secondary polymers, oil refining wastes paraffins and bitumens, wastes of coke and by-product process (for example, fusa), as well as the proposed binder in the form of a substandard urea product [2]. Since the midtwentieth century Europe has accumulated rich experience in using various types of bitumen and oil refining waste as a binder for producing fuel briquettes [3-5]. But this binder is not widely used due to the high environmental load when burning fuel briquettes. Cement-based inorganic binders, using lime and other inorganic compounds, were also widely used [6]. Fuel briquettes produced using inorganic binders have high strength, but at the same time they significantly increase the content of ballast - ash - part of briquettes, which negatively affects both the economic and technical components of the process of using briquettes for energy purposes.

\section{Materials and methods}

PJSC "Koks" together with the Department of Chemical Technology of Solid Fuel of Kuzbass State Technical University conducted research on briquetting a mixture of PJSC "Koks" coal and coke dust using various binders (Tables 1 and 2). It was decided to use coal and coke dust as a basis for fuel briquettes because they are the only types of waste generated at PJSC "Koks" in Kemerovo. The coal component has a high reactivity when fuel briquettes enter the combustion zone, which will positively affect the initiation of the briquette ignition process. At the same time, coke dust has a greater calorific value, which in turn leads to greater efficiency and fuel saving. The experience of scientists who obtained positive results when using a mixture of sintering coal with non-sintering carboncontaining wastes was also taken into account [7,8]. Before briquetting, coke and coal dust were processed by the method of oil sintering to reduce ash content, and then they were dried. Substandard urea in molten form, together with coke dust, was fed into the mixing extruder shown in Fig. 1, after which the mixture was sent to the compression mould shown in Fig. 2, where the briquetting process took place. Briquetting in this case was carried out by repeated contact between the press and the surface of the briquette. 


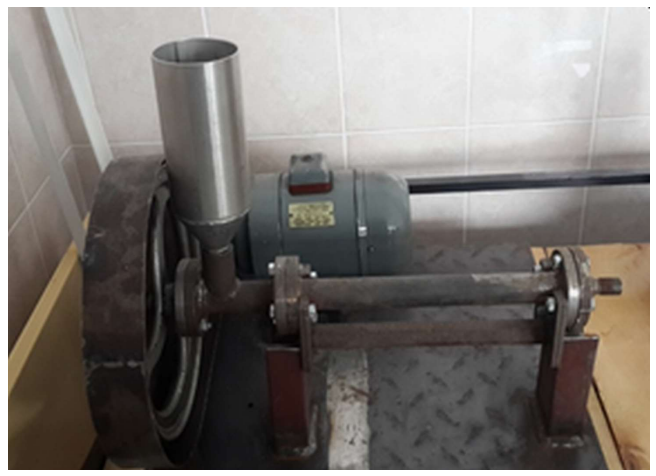

Fig. 1 The extruder-type mixing machine design.

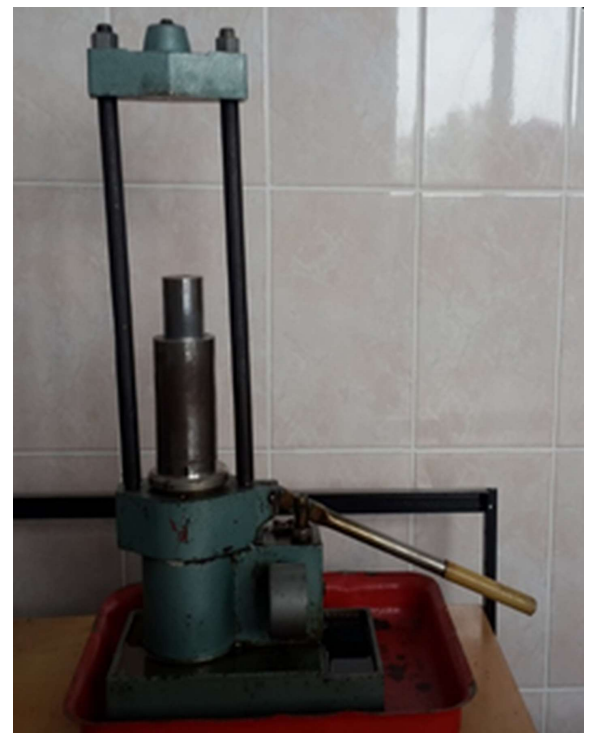

Fig. 2 The compression mold and the stamp press.

Table 1. Technical characteristics of briquettes

\begin{tabular}{|l|c|c|c|c|}
\hline \multicolumn{1}{|c|}{ Briquette type } & $\mathbf{A}^{\mathbf{d}}, \mathbf{\%}$ & $\mathbf{S t}^{\mathbf{d}} \mathbf{\%} \%$ & $\mathbf{V}^{\text {daf }}, \mathbf{\%}$ & $\mathbf{Q}_{\mathbf{B}}, \mathbf{k c a l} / \mathbf{k g}$ \\
\hline coal and coke dust + urea & 5,4 & 0,05 & 1,3 & 7600 \\
\hline $\begin{array}{l}\text { coal and coke dust + } \\
\text { secondary polymers }\end{array}$ & 6,4 & $0,8-1,0$ & 1,5 & 6900 \\
\hline coal and coke dust + bitumen & 6,2 & 0,1 & 1,7 & 7400 \\
\hline coal and coke dust + paraffin & 5,8 & 0,5 & 1,3 & 7100 \\
\hline $\begin{array}{l}\text { According to Specification } \\
\text { 0761-004-43058211-2005 [7] }\end{array}$ & $\begin{array}{c}\text { not } \\
\text { exceeding 16 }\end{array}$ & not exceeding 3 & 4,0 & - \\
\hline
\end{tabular}


Table 2. Strength characteristics of briquettes.

\begin{tabular}{|c|c|c|c|}
\hline Briquette type & $\begin{array}{c}\text { Compression, } \\
\mathbf{k g} / \mathrm{cm}^{2}\end{array}$ & $\begin{array}{c}\text { Abrasion, }>25 \\
\text { mm lump } \\
\text { content, \% }\end{array}$ & $\begin{array}{c}\text { Shatter, } \\
>25 \mathrm{~mm} \text { lump } \\
\text { content, \% }\end{array}$ \\
\hline pressed coal and coke dust & $10-14$ & 74 & 84 \\
\hline coal and coke dust + urea & $18-20$ & 90 & 96 \\
\hline $\begin{array}{l}\text { coal and coke dust }+ \text { secondary } \\
\text { polymers }\end{array}$ & $50-60$ & 99 & 99 \\
\hline coal and coke dust + bitumen & $13-15$ & 85 & 90 \\
\hline coal and coke dust + paraffin & $14-16$ & 88 & 94 \\
\hline
\end{tabular}

\section{Results and discussion}

From the data obtained, it can be seen that the coal and coke dust briquettes have small strength characteristics, which limits their transportation over long distances. When a binder is added, the strength characteristics of the briquettes are noticeably improved, but these characteristics can change depending on the type and properties of the binder. Briquettes made with the addition of secondary polymers have the greatest strength, however, the presence of sulfur in them significantly increases this indicator in briquettes, which, if used, can be harmful to the environment. Briquettes using urea as a binder have the best characteristics.

The produced briquettes are presented in Fig. 3.

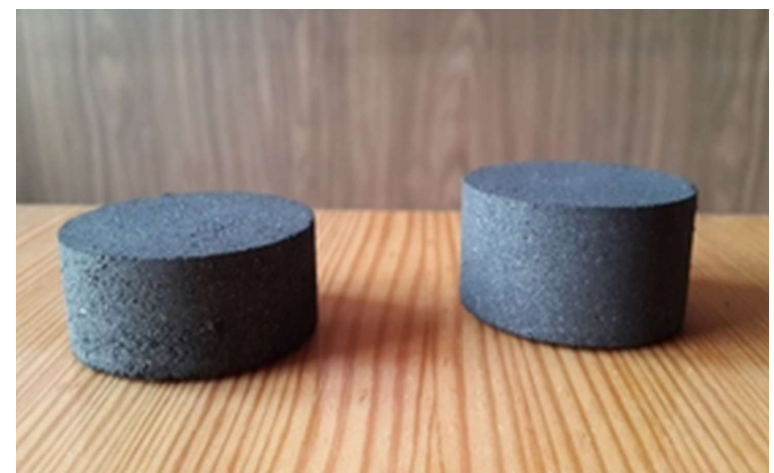

Fig. 3 Coal and coke dust briquettes with a substandard urea binder.

The dependence of strength characteristics on the type and concentration of the binder is shown in fig. 4 . Based on the analysis of the dependence of the abrasion of briquettes on the concentration of the binder, it can be concluded that briquettes produced with the addition of secondary polymers have low abrasion indices, and with an increase in the concentration of the binder over $5 \%(8 \%, 10 \%, 15 \%)$, the abrasion indices did not actually change. The highest content of over $25 \mathrm{~mm}$ lump after testing was shown by briquettes with the addition of urea. A dynamic decrease in the abrasion index is observed in the interval between $2 \%$ and $5 \%$ of the urea content in the briquette, then the abrasion index decreases with an increase in the concentration of the binder, however, the abrasion index does not change even within the binder content from $10 \%$ to $15 \%$. The abrasion indices of briquettes using bitumen as a binder are close to those of briquettes with paraffin. Briquettes using paraffin compared with the use of bitumen after testing gave a higher content of over 25 mm lumps. However, the dynamics of increasing the content of large lumps with an increase in the amount of binder between these two types of briquettes is close. Fig. 5 shows the dependence of the compressive strength of briquettes on the binder concentration. 


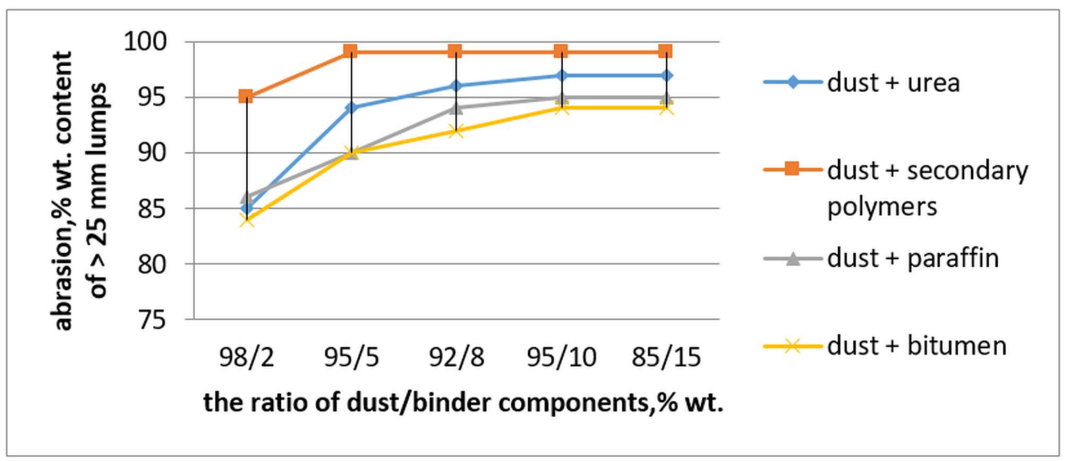

Fig. 4. The dependence of the abrasion of briquettes on the binder concentration.

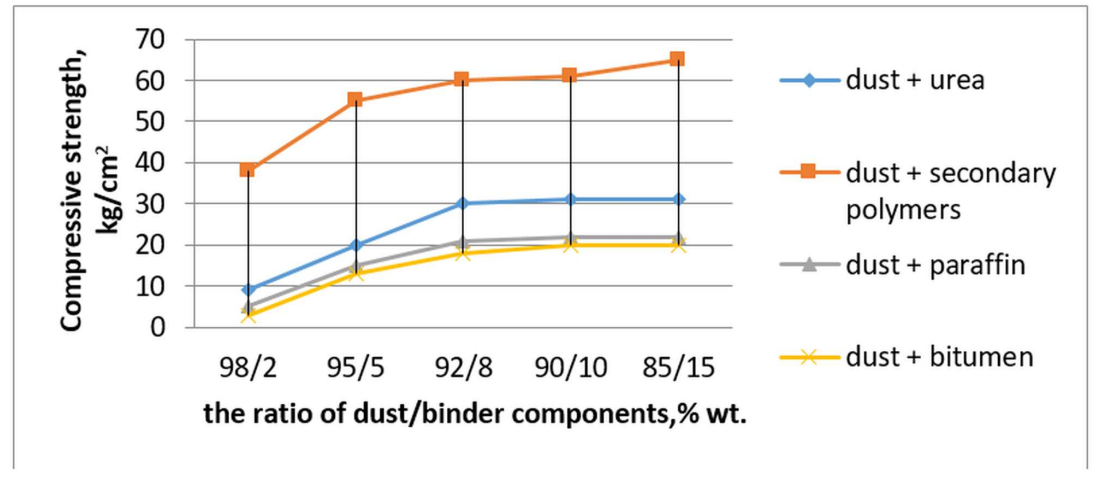

Fig. 5. The dependence of the compressive strength of briquettes on the binder concentration.

When analyzing the dependence, we can conclude that the greatest increase in the compressive strength index falls on the range of binder concentrations from $2 \%$ to $8 \%$, then the indicator remains unchanged. In the case of using secondary polymers as a binder, after adding $8 \%$ of the binder, the strength continues to increase markedly.

As a result of the analysis of the dependences of the briquette abrasion and strength indices on the binder concentration, it can be concluded that the briquette with the addition of urea as a binder has optimal values.

Studying the strength characteristics of briquettes, the briquetting method should be taken into consideration, since this condition significantly affects the strength characteristics of briquettes. In practice, various types of pressing are known. The most popular and simplest type of pressing is the single-stage contact molding, which is considered the traditional method. Impulse compression is also known, characterized by multi-stage contacting.

Figures 6, 7 and 8 show graphical dependences of the strength characteristics on the type of compression with a final load of $15 \mathrm{t} / \mathrm{cm}^{2}$. 


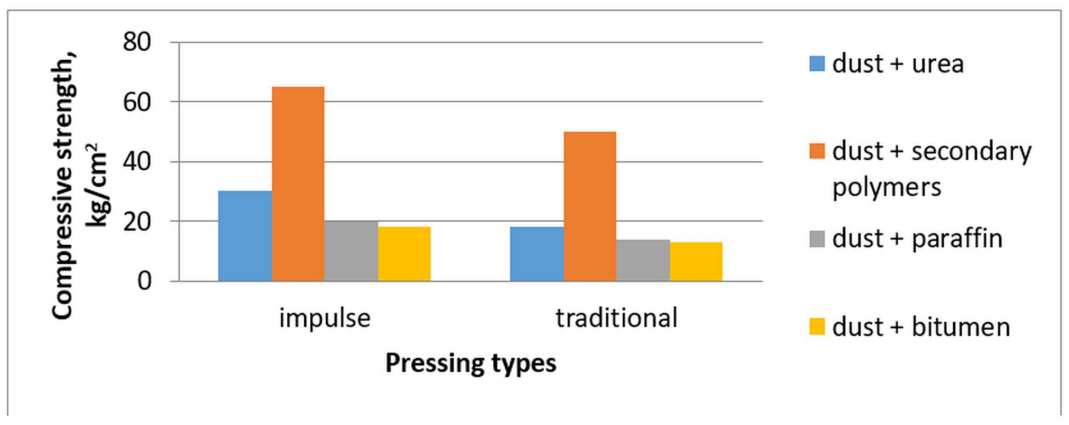

Fig. 6. The dependence of the compression strength of briquettes on the pressing type.

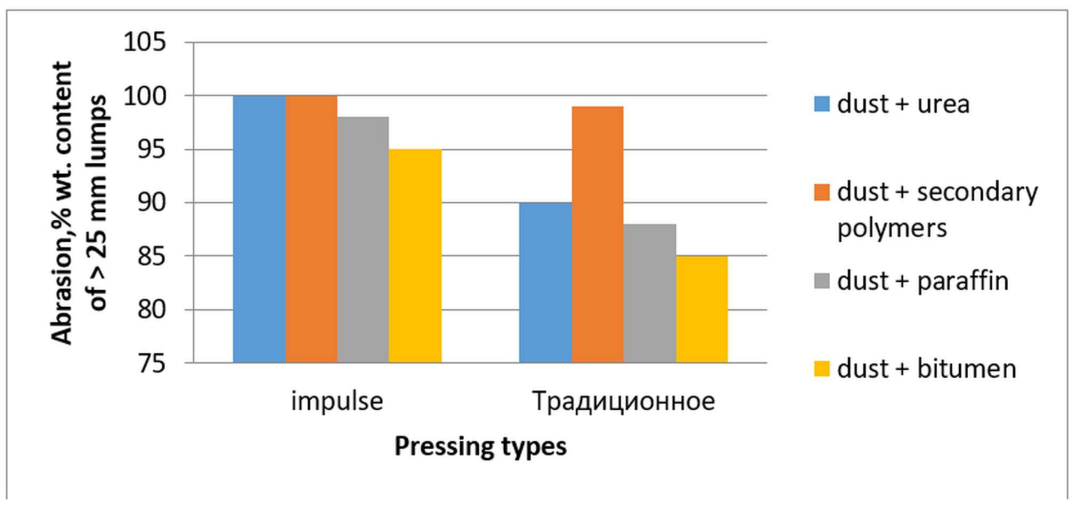

Fig. 7. The dependence of the abrasion resistance of briquettes on the pressing type.

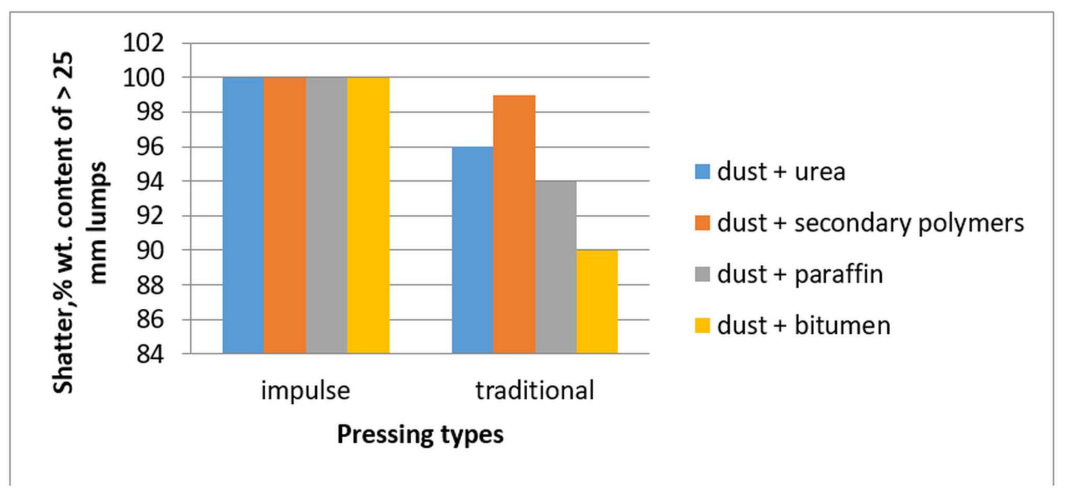

Fig. 8. The dependence of the shatter value of briquettes on the pressing type.

The analysis of the data shows that the multiple load on the fuel briquette (impulse briquetting) shows the best strength characteristics of the briquettes in comparison with the traditional pressing method. 


\section{Conclusion}

According to the results of the research conducted, it can be concluded that the use of waste of coal mining and coal processing enterprises is not only a rational technological solution for non-waste production, but also socially significant and environmentally attractive. The process of utilizing finely dispersed carbon-containing wastes is aimed not only at obtaining a new marketable type of fuel and at saving natural resources, but also at improving the environmental situation through the rational use of secondary material resources.

\section{References}

1. G. Komarek, K. Komarek, Patent Bulleting, 293708, 120 (1960)

2. I.Yu. Ryvkin, A.Ya. Eremin, Coke and chemistry, 10, 36-44 (2000)

3. P. Zakar, J. Toth Brikettierung mit Erdolbitumen als Bindemittel, 2, 1-10 (1958)

4. A. Vëchet, J. Chvostek, Paliva, 41, 350-353 (1961)

5. E. Gundermann, E. Knopfe, Freiberger Forschungsh, 238, 95-121 (1962)

6. K. Macqueen, B. Ernest, Patent Bulleting, 864737, 201 (1961)

7. I. Barbu, I. Stefanescu, N. Teodorescu, Cercetari metalurgice si miniere, 2, 389-416 (1960)

8. I. Blum, I. Nistor, Studii si cer. cetari energ. Acad RPR, 10:3, 563-575 (1960) 